INTERNATIONAL JOURN AL OF RESEARCHES IN BIOSCIENCES, AGRICULTURE AND TECHNOLOGY (c) VISHWASHANTI MULTIPURPOSE SOCIETY (Global Peace Multipurpose Socie ty) R. No. MH-659/13 (N) www.vmsindia.org

\title{
EFFECT OF FERROUS SULPHATE AND CALCIUM CARBONATE ON SEED GERMINATION, PLANT GROWTH AND SOLUBLE LEAF PROTEIN CONTENT OF MOTH BEAN (VIGNA ACONITIFOLIA JACQ.)
}

\section{G. S. Dhulgande, Manali Bagade and Puja Dhasade}

Department of Botany, Sir Parashurambhau College, Pune-30.

drgovind2012@gmail.com

\begin{abstract}
:
Some heavy metals in higher doses may cause metabolic disorders and growth inhibition for most of the plant species. This study was performed in order to evaluate the effect of calcium carbonate $\left(\mathrm{CaCo}_{3}\right)$ and ferrous sulphate $\left(\mathrm{FeSO}_{4}\right)$ on seed germination, seedling height and soluble leaf protein content of Moth Bean. The seeds were subjected se parately to different concentrations such as $1 \%$ and $2 \% \mathrm{w} / \mathrm{v}$ of each chemical solution. It was compared with controlled seeds. Results showed that the germination percentage and rate of germination was significant in all concentrations of both chemical solutions. However, the better germination occurred at $1 \%$ concentration of calcium carbonate in petriplate and $2 \%$ concentration of ferrous sulphate in soil condition. Also seedling height was calculated. The significant seedling height was recorde $\mathrm{d}$ at $1 \%$ concentrations of each che mical solution in petriplates as well as in soil conditions. Comparatively significant seedling height was recorded in non treated seeds in soil condition. Also among chemical solutions, calcium carbonate showed significant effect on seedling height in petriplate growth while ferrous sulphate showed significant effect on seedling height in soil condition. Soluble protein content was estimated from crude protein extract by Lowry method. The significant soluble protein content was recorded at $0.5 \mathrm{ml}$ crude protein extract of leaves treated by $2 \%$ ferrous sulphate chemical concentration. Same results were showed in control at $0.3 \% \mathrm{ml}$ crude prote in extract.

Our results exhibited that the fe rrous sulphate had more significant on parameters like seed germination, seedling height and soluble leaf prote in content.
\end{abstract}

Keywords: Moth bean, calcium carbonate, ferrous sulphate, soluble proteins.

\section{Introduction}

Heavy metals have recently received the attention of researchers all over the world, mainly due to their harmful effects on plant. Many studies demonstrated that heavy metals remarkably influence the seed germination and early seedling growth of plants. A few examples are summarized here: Effect of $\mathrm{Cu}$ on Helianthus annuus (Lin et al., 2003), $\mathrm{Cu}$ on Brassica oleracea (Chatte rjee and Chatterjee, 2000). It is known that metal sensitivity and toxicity to plants are influenced by not only the concentration and the toxicant types, but are also dependent to several developmental stages of the plants (Liu et al., 2005). Seed germination is one of the most highly sensitive physiological processes in plants and is regulated by several hormonal interaction and environmental factors (Iglesias and Babiano, 1996). In addition, seed germination is more sensitive to metal pollution because of a lack of some de fense mechanisms. It is well documented that germination process is highly disturbed by metal stresses (Youn-Joo An, 2006), hence, no desirable overlapping of seed germination would be obtained under heavy metal pollution. Therefore, seed germination behavior is necessary to be understood under adverse environmental conditions. Cereals and pulses are important sources of energy and protein and thus continue to occupy an important place in human nutrition particularly in the developing countries. Among the rural people in the arid regions of India who subsist on cereals and millets, Moth Bean is the main source of prote in and calories. Moth Bean is one of the major protein food source. It is rich in protein $(23.6 \mathrm{~g})$; calcium (202 $\mathrm{mg})$. It is an excellent supplement to cereal diet, especially for people who are unaware of the problems that malnutrition. Moth Bean is a cheap source of nutrients and forms a specific and perfect diet.

It has been observed that Moth Bean is an important and vital crop for arid areas. Its multipurpose personality and higher adaptability to uncongenial ecological environments makes it is a perfect choice for areas receiving lesser rainfall. However few genetic modifications to improve its varieties might help the crop as a National and International co mmercial crop.

Efforts are being made an improving all aspects of this Bean to bring its positives out in the entire world. Researchers are being made on its adaptation, genetic resources, genetic and agronomic improvements, plant protection 
strategies, biotechnological possibilities and quality considerations. And it has been taken care of that quality hybrids possessing all essential qualities should be produced.

However to the best of our knowledge, to date there is no report on the evaluation of germination, seedling growth and soluble prote in content of Moth Bean affected by ferrous and calcium metallic pollutant. The aim of this study is to evaluate the reaction of growing seed and fresh leaves of moth bean to different concentration of ferrous sulphate and calcium carbonate to determine seed germination, seedling height and leaf protein content

\section{Materials and Methods:}

\section{Plant material and Metal treatment:}

The present research work has been conducted in the Dept. of botany, S.P. College, Pune-30 (M.S.) in winter season. The local variety of moth bean was used for the experiment. The healthy seeds were selected and soaked in distilled water for 2 hours. The $1 \%$ and $2 \%$ concentration of $\mathrm{CaCO}_{3}$ and $\mathrm{FeSO}_{4}$ solutions were prepared in pure distilled wate $\mathrm{r}$ in laboratory. 50 selected healthy seeds of same size were soaked in $1 \%$ and $2 \%$ concentration of both chemical solutions. Then the treated seeds we re transferred to petridishes containing normal blotting papers used as sowing media along with control. Also equal seeds were sown in the soil for collection of fresh leaves. The petridishes were kept under $12 \pm 2$ hours photoperiodic condition in the laboratory germinator at room temperature for germination study and seedling growth. Seed treatment was repeated three times and the solutions were replenished every another day. The crite ria used for the seed germination was taken as immergence of plumules and radicals at the time of observation. The growth parameters like germination after 24 hours, seedling height after 48 hours and 72 hours were observed.

\section{Protein content analysis:}

Folin- Lowry method (Lowry et.al., 1951) was used to determine the total soluble prote in content of shoot.

\section{Statistical analysis:}

Experiment was conducted with 3 replication and five treatments. Statistical analysis was conducted one way analysis of variance (ANOVA).

\section{Results:}

Germination percentage and Rate of germination: Our study indicated that different concentration of these two compounds not affected the seed germination percentage. All seeds were germinated well, but it affects the rate of germination. $1 \%$ concentration of $\mathrm{CaCO}_{3}$ showed well rate of germination in petridish but less in soil condition. Similarly, $2 \%$ concentration of $\mathrm{FeSO}_{4}$ showed significant rate of germination in soil condition and less in petridish medium.
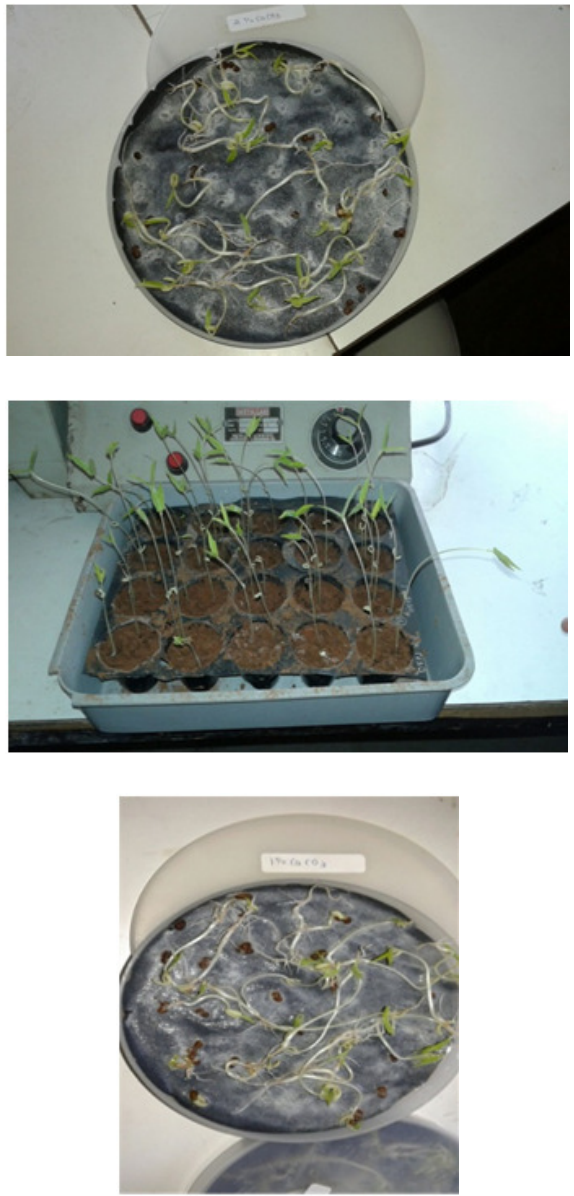

\section{Seedling height:}

Results pertaining to the seedling height were recorded that the higher concentration of $\mathrm{FeSO}_{4}$ had significant effe ct on reduction in the seedling height over control. Comparatively more seedling height was recorded in soil condition as compared to petridish medium. Remarkably the significant height was recorded at $1 \%$ concentration of $\mathrm{FeSO}_{4}(10.36 \mathrm{~cm})$ and $2 \%$ concentration of $\mathrm{CaCO}_{3}(9.43 \mathrm{~cm})$ (Table 1 and Figure 1$)$.

Total soluble protein content (gm/L):

A marked increase in total soluble protein content was observed $0.5 \mathrm{ml}$ crude protein extract at concentration of $\mathrm{FeSO} 4$ followed the control revealed total soluble protein content about $1.9 \mathrm{gm} / \mathrm{L}$. The protein 
content accumulation was more in seed treated by $\mathrm{CaCO}_{3}$ than $\mathrm{FeSO}_{4}$ (Table2 and Figure 2).

Table 1. Effect of $\mathrm{CaCo}_{3}$ and $\mathrm{FeSO}_{4}$ on seed germination percentage, seedling height $(\mathrm{cms})$ of Moth Bean.

\begin{tabular}{|l|l|l|l|}
\hline $\begin{array}{l}\text { Sr. } \\
\text { No } \\
\cdot\end{array}$ & $\begin{array}{l}\text { Concentratio } \\
\text { ns }\end{array}$ & $\begin{array}{l}\text { Germinatio } \\
\text { n } \\
\text { (\%) after 2 } \\
\text { days }\end{array}$ & $\begin{array}{l}\text { Seedling } \\
\text { he ight(cm } \\
\text { s) }\end{array}$ \\
\hline 1 & CONTROL & $100 \%$ & 10.77 \\
\hline 2 & $1 \% \mathrm{CaCO} 3$ & $100 \%$ & 8.10 \\
\hline 3 & $2 \% \mathrm{CaCO} 3$ & $100 \%$ & 9.43 \\
\hline 4 & $1 \% \mathrm{FeSO} 4$ & $100 \%$ & 10.36 \\
\hline 5 & $2 \% \mathrm{FeSO} 4$ & $100 \%$ & 9.36 \\
\hline
\end{tabular}

Table 2. Effect of $\mathrm{CaCo}_{3}$ and $\mathrm{FeSO}_{4}$ on soluble prote in contents in moth bean leaves.

\begin{tabular}{|l|l|l|l|l|l|l}
\hline $\begin{array}{c}\text { Sr. } \\
\text { No. }\end{array}$ & $\begin{array}{c}\text { Crude } \\
\text { protein } \\
\text { extract } \\
\text { (ml) }\end{array}$ & \multicolumn{5}{|c}{$\begin{array}{c}\text { Soluble protein content } \\
\text { at differe nt } \\
\text { concent rations (gm/L) }\end{array}$} \\
\hline 1 & BLANK & Nil & Nil & Nil & Nil & Nil \\
2 & 0.1 & 0.78 & 1.7 & 1 & 0.8 & 1 \\
\hline 3 & 0.2 & 1 & 1.2 & 0.7 & 0.8 & 0.8 \\
\hline 4 & 0.3 & 1.9 & 1 & 0.8 & 0.9 & 0.9 \\
\hline 5 & 0.4 & 1.2 & 1.2 & 1 & 1 & 0.9 \\
\hline 6 & 0.5 & 1.4 & 1.6 & 1.6 & $\mathbf{1 . 8}$ & $\mathbf{3}$ \\
\hline
\end{tabular}

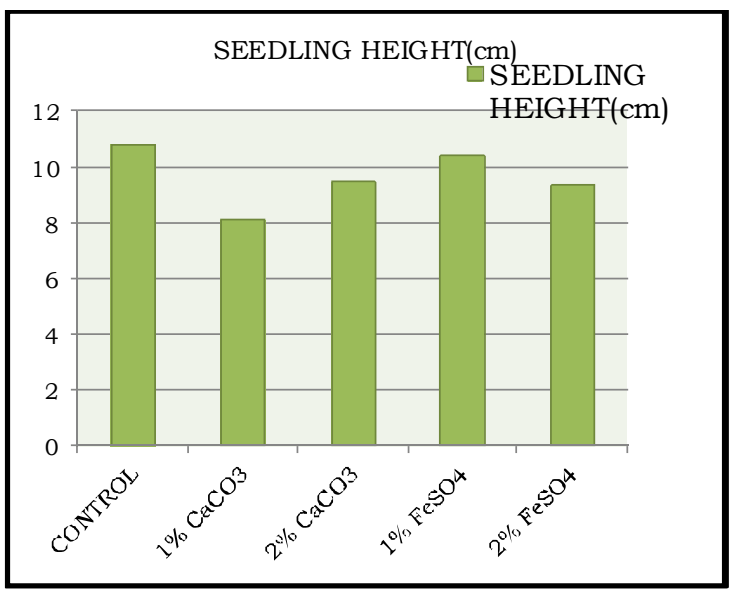

Figure 1. Interaction between Moth Bean and different concentrations of che mical substances on seedling height $(\mathrm{cms})$.

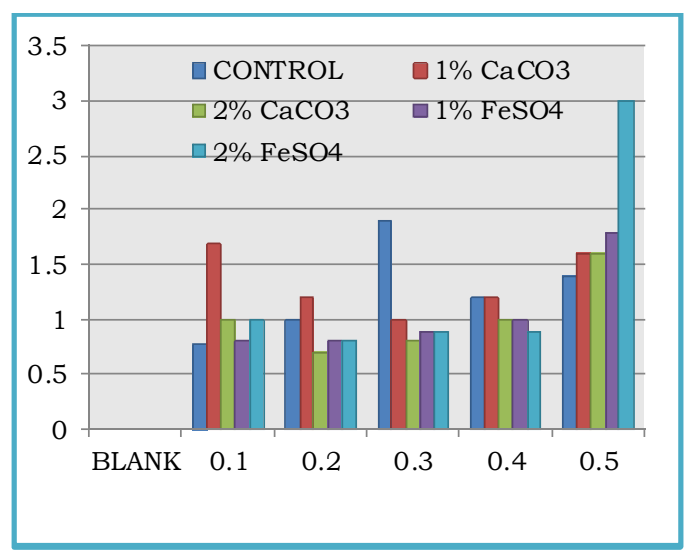

Figure 2. Interaction between Moth Bean and different concentrations of chemical substances on total soluble protein content $(\mathrm{gm} / \mathrm{L})$

\section{Discussion:}

Present study was focused on the rate of seed germination, seedling height and total soluble protein content at initial stage. The result of seed germination and rate of germination of Moth Beans were found to be more than $98 \%$, and it was not influenced by different concentrations of $\mathrm{CaCO}_{3}$ and $\mathrm{FeSO}_{4}$ compound.

The seedling height of Moth Bean significantly decreases in increase in concentration of both substances as compared to normal in both petridish as well as in soil media. Similar results were reported by Shen et. al., 1998, that $\mathrm{Cu}$ and $\mathrm{Zn}$ toxicity might cause multiple direct and indirect influences on all procedures of plant growth and development. The decrease in seedling height was due to reduction in cell division, similar finding has been reported by Souguir et. al., 2008. The total soluble protein content of leaves was recorded to be decreased with an increase in concentration, might be due to defense mechanism resulting in higher concentration of various enzymes involved in different prote in synthes is pathway.

\section{Conclusion:}

From present study it was revealed that the $\mathrm{CaCO}_{3}$ had more inhibitory effect on seed germination, rate of germination, seedling height and total soluble protein content than $\mathrm{FeSO} 4$. Finally we can conclude that $\mathrm{FeSO} 4$ is significant compound in lower concentration for studied parameters. Also concentration of the compound must not more than $0.1 \%$ in substrate. 


\section{Acknowledgement:}

Authors are thankful to Head, Department of Botany S. P. College, Pune-30 for providing laboratory facility to complete this work. We are also thankful to Head, Departme nt of Chemistry for their valuable help during this work. Last but not least our since re thanks to senior colleague for their valuable guidance and moral support during this work.

\section{References:}

Chatterjee J, Chatte rjee C. 2000: Phyto toxicity of cobalt, chromium and copper in cauliflower. Environ Pollut 109: 69-74.

Iglesias RG, Babiano MJ. 1996: ABA levels in chick-pea seeds during the first twenty-four hours of germination. Effect of polyethyleneglycol. Phytoche mis try 41: 681683.

Lin J, Jiang W, Liu DC 2003: Accumulation of copper by roots, hypocotyls, cotyledons and leaves of sunflower (Helianthus annuus L.). Bioresour Technol Jan; 86(2):151-5.
Liu X, Zhang S, Shan X, Zhu YG. 2005: Toxicity of arsenate and arsenite on germination seedling growth and amylolytic activity of whe at.Chemosphere 61:293-301.

Lowry, O.H., Rosebrough, N.J., Farr, A.L., and Randall, R.J. 1951: J.Biol.Chem 193: 265 (Theoriginal method).

Shen, Z., Z. Fenqin and Z. Fusuo, 1998: Toxicity of copper and zinc in seedlings of Mung bean and inducing accumulation of polyamine. J. Plant Nut., 21:1153-1162.

Souguir, D., E. Ferjani, G. Ledoigt and P. Goupil, 2008: Exposure of vicia faba and Pisum sativum to copper-induced genotoxicity. Protoplasma, 233: 203-207.

Xiong ZT, Wang H. 2005: Copper toxicity and bioaccumulation in Chinese cabbage (Brassica pekinensis Rupr.). Environ Toxicol 20: 188-194.

Youn-Joo A. 2006: Assessment of comparative toxicities of lead and copper using plant assay. Chemosphere 62:1359-1365. 